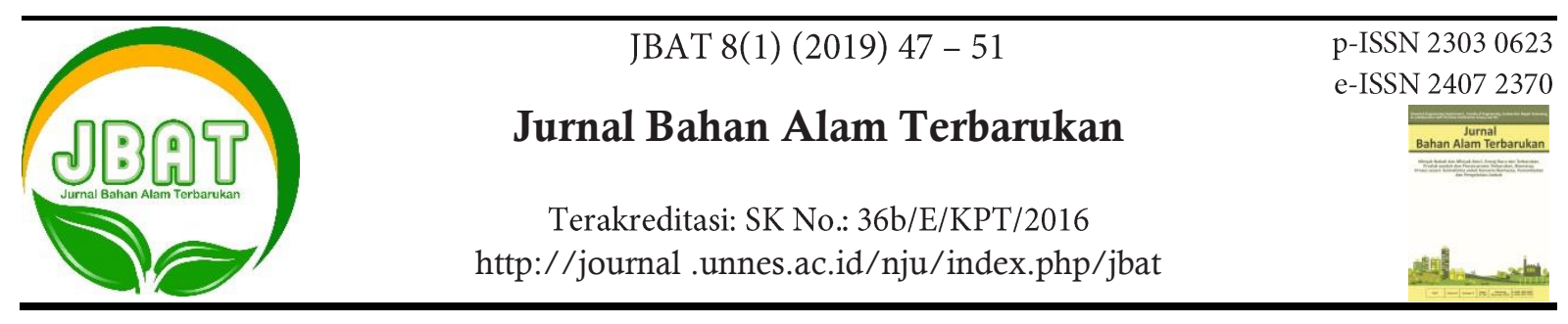

\title{
The Utilization of Fiddle-Leaf Fig Waste Into Food Preservative
}

\author{
Erna Astuti, Zahrul Mufrodi ${ }^{凶}$
}

DOI 10.15294/jbat.v8i1.19859

Department of Chemical Engineering, Universitas Ahmad Dahlan, Ring Road Selatan Street, Tamanan, Banguntapan, Bantul, Indonesia 55166

\begin{tabular}{|c|c|}
\hline Article Info & Abstract \\
\hline $\begin{array}{l}\text { Article history: } \\
\text { Received } \\
\quad \text { April } 2019 \\
\text { Accepted } \\
\quad \text { June } 2019 \\
\text { Published } \\
\quad \text { June 2019 } \\
\text { Keywords : } \\
\text { Fiddle-leaf Fig; } \\
\text { Pyrolysis; } \\
\text { Gas chromatography } \\
\text { mass spectrometry; } \\
\text { Food preservative }\end{array}$ & $\begin{array}{l}\text { Fiddle-leaf Fig is a tree that is widely used as a protective or plants or shade. This plant is } \\
\text { usually found on the side of the road, in the office area and as houseplants. The presence of } \\
\text { fiddle-leaf fig leaves that fall from the tree will be a waste for the environment. This study } \\
\text { proposes utilization of fiddle-leaf fig waste by pyrolysis method using pyrolysis triple } \\
\text { condenser. Thermal analysis was done before experiments using a thermo gravimetric } \\
\text { analyzer in the range of temperature of room temperature until } 1000^{\circ} \mathrm{C} \text {. Process was carried } \\
\text { out at heating temperature of } 350^{\circ} \mathrm{C}, 375^{\circ} \mathrm{C}, 400^{\circ} \mathrm{C}, 425^{\circ} \mathrm{C}, 450^{\circ} \mathrm{C}, 475^{\circ} \mathrm{C} \text { and } 500^{\circ} \mathrm{C} \text {. The } \\
\text { product of pyrolysis were obtained from liquid coming out from the residue container, the } \\
\text { first and second condenser, and the smoke is coming out from the third condenser. The } \\
\text { smokes were absorbed with water. Further, all of the liquid were analyzed by gas } \\
\text { chromatography mass spectrometry (GCMS). The analysis results show that the main } \\
\text { components of pyrolysis liquid products are carboxylic acids, ketones, alcohols, and alkanes. } \\
\text { There is gasoline and kerosene in the liquid, so it has the potential to become bio-oil. The } \\
\text { largest potential of fiddle-leaf fig waste is as raw material for food preservative because it } \\
\text { contains many carboxylic acid compounds. }\end{array}$ \\
\hline
\end{tabular}

\section{INTRODUCTION}

Environmental issues are one of the most important and most noteworthy issues in recent years. One of the most frequently highlighted environmental issues is global warming. One solution is to increase the preservative plants in the public area, on the side of the road, in the office area and in house. The planted tree has many benefits: as an oxygen producer, flood prevention and landslide, reduce air pollution and reduce global warming. One type of preservative plant is a fiddleleaf fig tree. Fiddle-leaf fig (ficus lyrata) is a plant that is also referred as bush plants. This plant comes from tropical rain forests west and central Africa. This plant is the most studied and beautiful species and is known as an ornamental plant in Europe and North America. This plant is also widely grown in Indonesia. This plant can grow up to 9-12 $\mathrm{m}$ with a leaf length of $30-45 \mathrm{~cm}$ and a width of $25 \mathrm{~cm}$ (Beffa, 2007). This tree produce organic waste in the form of dried leaves and dry twigs. The presence of fiddle-leaf fig leaves that fall from the tree will be a waste. The waste is potential to increase environmental problems so it needs to be converted into other more useful products. This research proposes the potential utilization of organic waste of fiddle-leaf fig leaves into food preservative by pyrolysis process.

Pyrolysis is a method of cracking a substance into a new substance by heating in a very limited amount of Oxygen. Pyrolysis is a major thermal process used to convert solids into different gases, liquids and solids. This is the first stage of the thermal splitting process before the gasification stage and the combustion stage (Kantarelis et al., 2012). Pyrolysis is divided into 3 types namely slow pyrolysis, intermediate and fast pyrolysis. Slow

\footnotetext{
${ }^{\square}$ Corresponding author:

Department of Chemical Engineering, Universitas Ahmad Dahlan,

Ring Road Selatan Street, Tamanan, Banguntapan, Bantul, Indonesia 55166

E-mail: zahrul.mufrodi@che.uad.ac.id
} 
pyrolysis is a process of making charcoal that takes place at a temperature of $400^{\circ} \mathrm{C}-800^{\circ} \mathrm{C}$ with a heating rate below $10^{\circ} \mathrm{C}$ per minute and takes a very long time. Fast pyrolysis or also known as flash pyrolysis is a method to produce bio-oil (Brownsort, 2009). Fast biomass pyrolysis is an effective process to produce bio-oils (Cavalloti et al., 2018). Rapid pyrolysis typically uses small feedstocks of less than $2 \mathrm{~mm}$ and has a shorter steam tiggal time (Brownsort, 2009). Intermediate pyrolysis is similar to the fast pyrolysis process but with a slightly longer residence time. This process was developed to utilize more difficult to handle raw materials such as waste of lumpu, grass and algae (Mahmood et al., 2013). Slow pyrolysis is produce liquid smoke with the greatest water content $(70 \%)$, phenol, carboxylic acid and carbonyl. While fast pyrolysis produce organic vapor mixture such as acid, alcohol, aldehyde, ether, ester, ketone, furan, phenol, acetaldehyde, butanedion, methanol, and hydrocarbon (Serapiglia et al., 2017).

Some research on pyrolysis has been done. Sukiran et al (2009) conducts the process of fast pyrolisis empty palm oil bunch at optimum temperature of $500^{\circ} \mathrm{C}$ with $91-106 \mu \mathrm{m}$ biomass particle size. This process obtained maximum biooil of $42.28 \%$. In another study conducted by Ningrum (2011) using shell, bunch and palm fiber and $550^{\circ} \mathrm{C}$, the maximum shell conversion was $62 \%$ and the maximum conversion of bunches was $50.7 \%$. Debiagi et al. (2018) have done biomass pyrolysis and explained the yield, composition and active surface. The aim of this paper is determine the thermal analysis of fiddle-leaf fig and look for utilization of liquid produce from pyrolysis.

\section{METHODS}

\section{Thermal Analysis}

Thermal analysis of fiddle-leaf fig sample was done by using a thermogravimetric analyzer (Perkin Elmer, Pyris diamond). Sample was heated from 30 to $1000^{\circ} \mathrm{C}$ at a rate of $10^{\circ} \mathrm{C} / \mathrm{min}$ in the presence of nitrogen.

\section{Pyrolysis}

Fiddle-leaf fig leaves were collected from main campus area of Universitas Ahmad Dahlan. The leaves were cleaned from sand and soil, and then were dried with the sun for 3 days. The leaves were cut to size about $2 \mathrm{~mm}$. hereafter, the leaves were inserted in the pyrolysis equipment. The process were run with variate temperature: $350^{\circ} \mathrm{C}$, $375^{\circ} \mathrm{C}, 400^{\circ} \mathrm{C}, 425^{\circ} \mathrm{C}, 450^{\circ} \mathrm{C}, 475^{\circ} \mathrm{C}$ and $500^{\circ} \mathrm{C}$. The product of pyrolysis were obtained from liquid coming out from the residue container, the first and second condenser, and the smoke is coming out from the third condenser. The smokes were absorbed with water. Further, all of the liquid were analyzed by gas chromatography mass spectrometry (GCMS).

\section{RESULTS AND DISCUSSION}

\section{Thermal Analysis Results}

In the begining of research, the analysis by thermogravimetric analysis (TGA) were done. TGA is a technique to measure the amount and rate in weight of the material as a funcion of temperature. This technique can exhibit the reduction of weight because of oxidation, decomposition et al. The thermal degradation behaviors at different compaction temperatures are represented in TGA and DTG curves and peaks (Wattana and Kittayaruksakul, 2016). Thermogravimetric analysis, Differential Thermal Analyzer (DTA) and Differential Scanning Calorimetric (DSC) analyzer can be used to investigate the effects of reaction atmosphere on thermal chemical characteristics (Ram et al., 2014). The result of TGA of fiddle-leaf fig is expressed at the Figure 1.

As it can be seen in Figure 1, from ambient temperature to $230^{\circ} \mathrm{C}$, moisture and light volatile matter is abolished. Hereafter the matter constantly decrease rapidly at temperature of $230^{\circ} \mathrm{C}$ to $350^{\circ} \mathrm{C}$. After that, the speed of weight loss is almost the same at temperature ranging of $350^{\circ} \mathrm{C}$ to $1000^{\circ} \mathrm{C}$.

The DTA of fiddle-leaf fig was shown at Figure 2. The temperatures at which maximum rate of weight loss occurred are indicated by the position of the peaks in the curve (Wattana \& Kittayaruksakul, 2016). As shown in figure 2, only one peak was formed from pyrolysis of fiddle-leaf fig leaves. The maximum temperature is $340^{\circ} \mathrm{C}$.

\section{Pyrolysis Results}

In this research, liquid product identification was done by using GC-MS method. This identification was performed to determine the distribution of compound components and functional groups in the pyrolysis product of liquid. The result of the analysis by GC-MS method is presented in Table 1. 


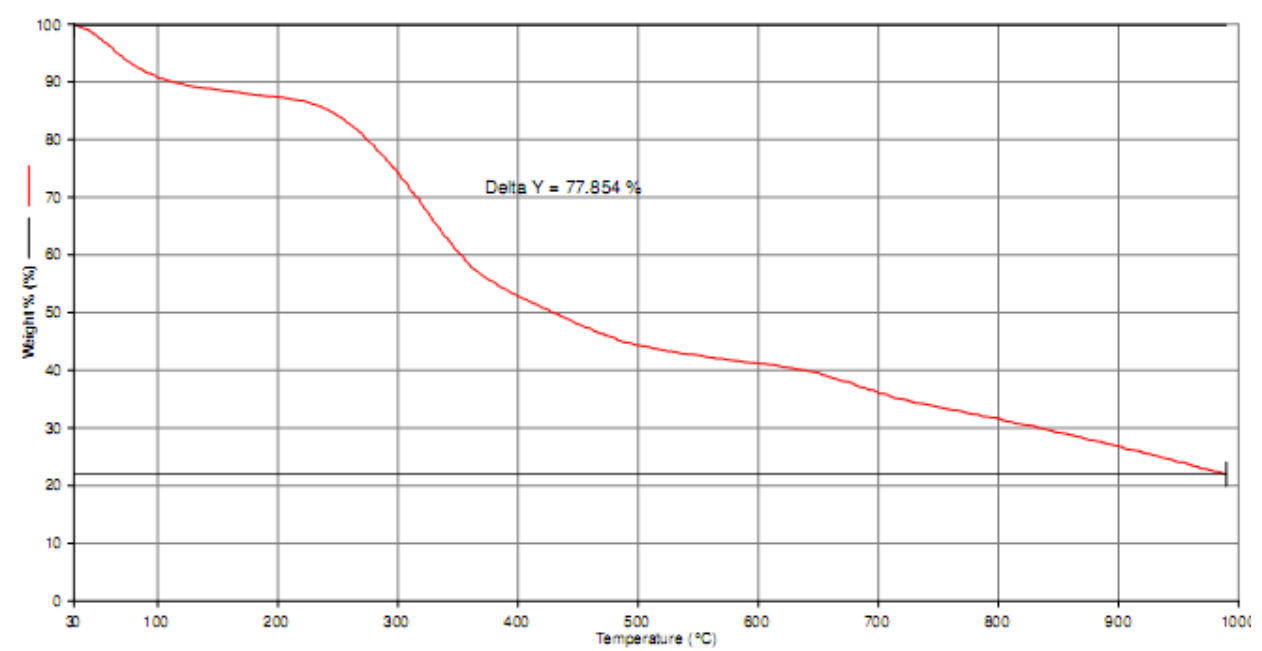

Figure 1. The effect of pyrolysis to the reduction of weight of fiddle-leaf fig.

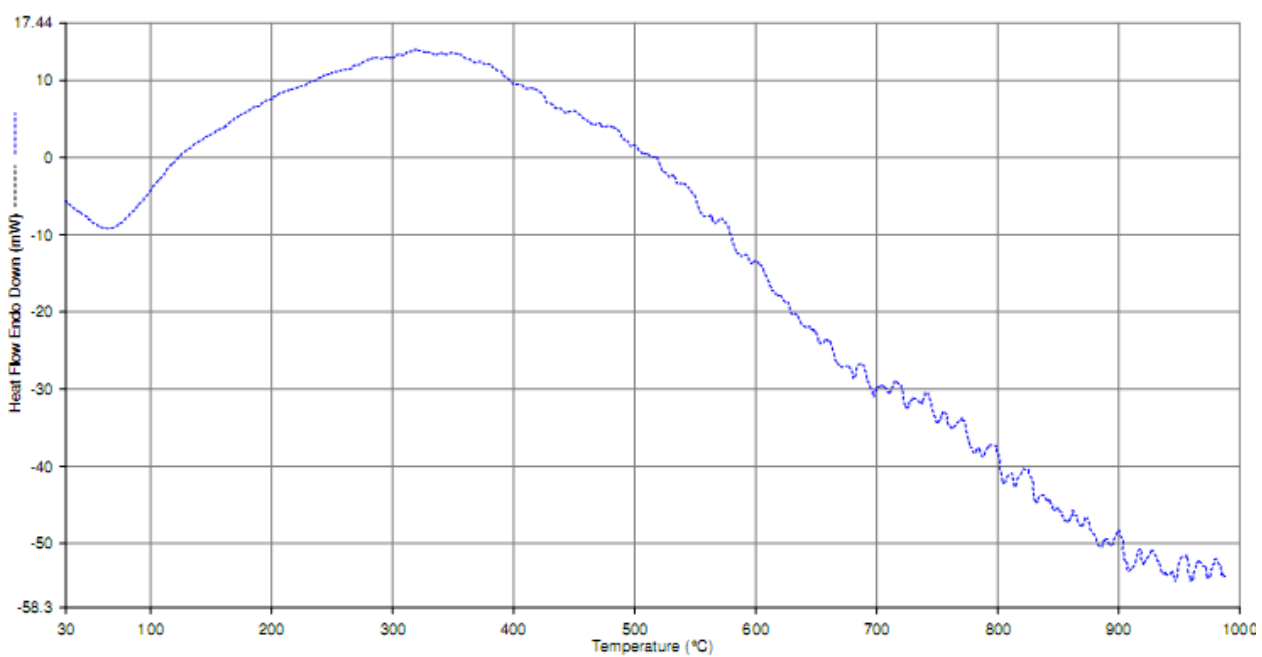

Figure 2. Differential Thermal Analyzer of fiddle-leaf fig.

Table 1 Results of GC-MS analysis of liquid products in percent weight (\%)

\begin{tabular}{|c|c|c|c|c|c|c|c|c|c|c|c|c|c|c|}
\hline \multirow{4}{*}{$\begin{array}{l}\text { Funct. } \\
\text { group }\end{array}$} & \multicolumn{14}{|c|}{ \% weight } \\
\hline & \multirow{2}{*}{\multicolumn{2}{|c|}{$\begin{array}{c}350^{\circ} \mathrm{C} \\
\text { condensor }\end{array}$}} & \multirow{2}{*}{\multicolumn{3}{|c|}{$\begin{array}{c}425^{\circ} \mathrm{C} \\
\text { Residue }\end{array}$}} & \multirow{2}{*}{\multicolumn{3}{|c|}{$\begin{array}{c}450^{\circ} \mathrm{C} \\
\text { Residue }\end{array}$}} & \multirow{2}{*}{\multicolumn{2}{|c|}{$\begin{array}{c}475^{\circ} \mathrm{C} \\
\text { Residue }\end{array}$}} & \multicolumn{4}{|c|}{$500^{\circ} \mathrm{C}$} \\
\hline & & & & & & & & & & & \multicolumn{2}{|c|}{ Residue } & \multicolumn{2}{|c|}{ condensor } \\
\hline & $\begin{array}{c}\mathrm{U} \\
(\%)\end{array}$ & $\begin{array}{c}\text { B } \\
(\%)\end{array}$ & $\begin{array}{l}\text { UP } \\
(\%)\end{array}$ & $\begin{array}{l}\text { DP } \\
\text { (\%) }\end{array}$ & $\begin{array}{l}\text { BD } \\
(\%)\end{array}$ & $\begin{array}{l}\text { UP } \\
(\%)\end{array}$ & $\begin{array}{l}\text { DP } \\
(\%)\end{array}$ & $\begin{array}{l}\text { BD } \\
(\%)\end{array}$ & $\begin{array}{l}\text { TD } \\
(\%)\end{array}$ & $\begin{array}{l}\text { BD } \\
(\%)\end{array}$ & $\begin{array}{l}\text { TD } \\
(\%)\end{array}$ & $\begin{array}{l}\text { BD } \\
(\%)\end{array}$ & $\begin{array}{c}\text { HAD } \\
(\%)\end{array}$ & $\begin{array}{l}\text { BD } \\
\text { (\%) }\end{array}$ \\
\hline Alkane & - & - & 41.4 & 21.5 & - & 43.9 & 7.6 & 2.5 & 5.4 & - & 2.7 & - & 4.3 & 6.6 \\
\hline Alkene & - & - & 23.3 & - & - & 23.0 & 34.8 & - & 3.6 & - & 6.4 & - & - & 4.8 \\
\hline Alcohol & 39.1 & 40.4 & 2.0 & 20.2 & - & 4.3 & 13.0 & - & 15.3 & - & 23.9 & - & 65.2 & 6.9 \\
\hline Keton & 32.5 & 6.4 & 2.1 & 16.2 & 7.5 & - & 10.7 & 2.6 & 13.6 & - & 17.8 & 3.6 & 4.4 & 7.2 \\
\hline Aromatic & 4.2 & 10.9 & 25.2 & - & 81.3 & 22.3 & - & - & 4.8 & - & 8.0 & - & 3.9 & 3.6 \\
\hline Carboxilic & & & & & & & & & & & & & & \\
\hline $\begin{array}{l}\text { acid } \\
\text { alkil }\end{array}$ & 9.2 & 13.1 & 3.8 & 21.6 & - & - & 13.8 & 91.5 & 20.4 & 91.5 & 31.6 & 82.7 & 6.6 & 51.8 \\
\hline halide & - & 8.2 & - & - & - & - & 13.4 & - & - & - & - & 4.0 & 5.3 & - \\
\hline Ester & - & 6.4 & - & 4.2 & 4.4 & - & - & - & - & - & - & - & - & 3.5 \\
\hline Eter & - & 3.9 & - & 6.1 & - & - & - & - & - & - & - & - & - & - \\
\hline Phenol & 0.1 & 0.4 & - & - & - & - & 2.5 & - & 0.6 & 0.1 & 0.28 & - & 0.7 & - \\
\hline
\end{tabular}

abbreviation:
A = Upper Phase
$\mathrm{B}=$ Bottom Phase
UP=Upper Phase Distilate
DP $=$ Down Phase Distillate
$\mathrm{BD}=$ Bottom Distillation Result $\mathrm{TD}=$ Top Distillation Result 
Table 2. The composition of each of the pyrolysis results.

\begin{tabular}{|c|c|c|c|c|c|c|c|c|c|c|c|c|c|c|}
\hline \multirow{4}{*}{$\underset{\mathrm{C}}{\text { Atom }}$} & \multicolumn{14}{|c|}{ \% weight } \\
\hline & \multirow{2}{*}{\multicolumn{2}{|c|}{\begin{tabular}{c|}
$350^{\circ} \mathrm{C}$ \\
condensor \\
\end{tabular}}} & \multirow{2}{*}{\multicolumn{3}{|c|}{$\begin{array}{c}425^{\circ} \mathrm{C} \\
\text { Residue } \\
\end{array}$}} & \multirow{2}{*}{\multicolumn{3}{|c|}{$\begin{array}{c}450^{\circ} \mathrm{C} \\
\text { Residue } \\
\end{array}$}} & \multirow{2}{*}{\multicolumn{2}{|c|}{$\begin{array}{c}475^{\circ} \mathrm{C} \\
\text { Residue } \\
\end{array}$}} & \multicolumn{4}{|c|}{$500^{\circ} \mathrm{C}$} \\
\hline & & & & & & & & & & & \multicolumn{2}{|c|}{ Residue } & \multicolumn{2}{|c|}{ condensor } \\
\hline & $\begin{array}{c}\mathbf{U} \\
(\%)\end{array}$ & $\begin{array}{c}\text { B } \\
(\%)\end{array}$ & $\begin{array}{l}\mathbf{U P} \\
(\%)\end{array}$ & $\begin{array}{l}\text { DP } \\
(\%)\end{array}$ & $\begin{array}{l}\text { BD } \\
(\%)\end{array}$ & $\begin{array}{l}\text { UP } \\
(\%)\end{array}$ & $\begin{array}{l}\text { DP } \\
(\%)\end{array}$ & $\begin{array}{l}\text { BD } \\
(\%)\end{array}$ & $\begin{array}{l}\text { TD } \\
(\%)\end{array}$ & $\begin{array}{l}\text { BD } \\
(\%)\end{array}$ & $\begin{array}{l}\text { TD } \\
(\%)\end{array}$ & $\begin{array}{l}\text { BD } \\
(\%)\end{array}$ & $\begin{array}{c}\text { HAD } \\
(\%)\end{array}$ & $\begin{array}{l}\text { BD } \\
(\%)\end{array}$ \\
\hline C1-C4 & - & 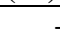 & - & - & - & 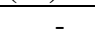 & - & - & - & - & - & - & - & - \\
\hline C4-C7 & - & . & - & - & - & - & 1.88 & - & 0.15 & - & 4.59 & - & 0. & - \\
\hline C7-C11 & - & 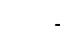 & 1.81 & - & - & 1.11 & 1.88 & 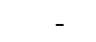 & 0.15 & - & 4.5 & - & 0. & - \\
\hline C10-C16 & 50.04 & . & 6.40 & 3.83 & 0.04 & 4.44 & 36.95 & - & - & 0.02 & 3.0 & 0.01 & 0.19 & 0.12 \\
\hline C12-C19 & 0.04 & . & 5.89 & 4.89 & 0.04 & 4.14 & 36.95 & 0.05 & - & 0.02 & 3.04 & 0.01 & 0.19 & 0.12 \\
\hline C16-C28 & 0.04 & . & 1.64 & 4.89 & 0.04 & 1.40 & 37.13 & 0.12 & - & 0.02 & 3.04 & 0.17 & 0.19 & 0.12 \\
\hline$>\mathrm{C} 25$ & . & . & 0.19 & - & - & 0.23 & . & 0.27 & - & - & - & 0.01 & - & - \\
\hline
\end{tabular}

Table 1 show that the major components of pyrolysis liquid products are carboxylic acids, ketones, alcohols, phenols and alkanes. The pyrolysis fluid from this experiment can burn. The alcohol compounds contained in this pyrolysis product can increase the burning capability of the liquid product, but since this liquid product still has water content, the combustion process of this liquid product is still relatively long. At pyrolysis temperature of $500^{\circ} \mathrm{C}$, there are ethanol compounds that come out on first condenser. With the existence of these compounds then this material has the potential to be used as bioethanol. The pyrolysis product contains many carboxylic acids in the top yield distillation residue of $500^{\circ} \mathrm{C}$. Table 1 also determines that the main product of pyrolysis at temperature of $450^{\circ} \mathrm{C}$ and above is carboxylic acid. Carboxylic acid compounds have many benefits in the food, pharmaceutical and other industries. Food ingredients that are often used in the food industry are acetic acid, benzoic acid, propionic acid, sorbic acid and epoxide compounds. All of these acids include the carboxylic acid function group. Jarboe et al (2013) state these carboxylic acids are routinely used as food preservatives. So the product of pyrolysis of fiddle-leaf fig leaves has potential to be a food preservative. Phenol is in the upper phase of distillate residue of $450^{\circ} \mathrm{C}$. Maqsood et.al (2013) determined that phenolic compounds are potential to be natural food additives in fish and fish products. Development of rancid odor and unpleasant flavor, changes of color and texture as well as lowering nutritional value in fish can be prevented by using this additives.

This research also evaluate carbon bond from the liquid that produce from pyrolysis. The composition in the pyrolysis results are listed in Table 2.

Table 2 shows that there is no $\mathrm{C} 1-\mathrm{C} 4$ in all results. The gasoline content $(\mathrm{C} 7-\mathrm{C} 11)$ is obtained from pyrolysis temperature of $425^{\circ} \mathrm{C}$ up to $500^{\circ} \mathrm{C}$.
The largest gasoline content is obtained at $450^{\circ} \mathrm{C}$. Meanwhile kerosene content is obtained at all temperatures. The highest kerosene were obtained at $450^{\circ} \mathrm{C}$. It can be concluded that pyrolysis of fiddle-leaf fig also has the potential to produce biooil. Bio-oil can be developed into biodiesel. Fiddleleaf fig pyrolysis potential to be a food preservative is greater than the potential for biodiesel.

\section{CONCLUSION}

Analysis of the number of atoms of liquid pyrolysis results stated that there is gasoline and kerosene in the liquid, so it has the potential to become bio-oil. The pyrolysis product also contains many carboxylic acids so it has potential to be a food preservative and pesticide. Fiddle-leaf fig leaves can be used as raw material to produce biooil, food preservatives. The largest potential of fiddle-leaf fig leaves waste is as raw material for food preservative because it contains many carboxylic acid compounds.

\section{ACKNOWLEDGEMENT}

The authors gratefully acknowledge the financial support for this research provided by The Center for Energy and Environment, Universitas Ahmad Dahlan, and Baharuddin, Dwi Ariyanto, Dicki Sanjaya and Feby Helki which help this research.

\section{REFERENCES}

Beffa M. T. D. 2007. Plante de apartament, Edit. All, Bucureşti

Brownsort, P. A. 2009. Biomass Pyrolysis Process: Review of Scope, Control and Variability. UK Biochar Research Centre. Edinburgh 
Cavallotti, C., Cuoci, A., Faravelli, T. , Frassoldati, A., Pelucchi, M., Ranzi, E. 2018. Detailed Kinetics of Pyrolysis and Combustion of Catechol and Guaiacol, as Reference Components of Bio-Oil from Biomass. Chemical Engineering Transactions. 65: 79-84

Debiagi, P. E. A., Gentile, G., Cuoci, A., Frassoldati, A., Ranzi, E., Faravelli,T. 2018. Yield, Composition and Active Surface Area of Char from Biomass Pyrolysis. Chemical Engineering Transactions. 65: 97-102

Jarboe, L. R., Royce, L. A, Liu, P. 2013. Understanding Biocatalyst inhibition by carboxylic acids. Frontiers in Microbiology. 4(272): 1-8

Kantarelis, E., Yang, W., Blasiak, W. 2012. Biomass pyrolysis for energy and fuel production. in Technologies for Converting Biomass to Useful Energy. CRC Press. 245-277

Mahmood, A. S. N. Brammer, J. G., Steele, A., Poulston, S. 2013. The intermediate pyrolysis and catalytic steam reforming of Brewers spent grain. Journal of Analytical and Applied Pyrolysis. 103: 328-342.

Maqsood, S., Benjakul, S., Shahidi, F. 2013. Emerging role of phenolic compounds as natural food additives in fish and fish products. Critical Reviews in Food Science and Nutrition. 53(2): 162-79.
Ningrum, A. O. 2011, Proses Pembuatan Biooil Dari Limbah Kelapa Sawit (Tandan, Cangkang, Dan Serat) Untuk Bahan Bakar Alternatif Dengan Metode Fast Pyrolysis (The Process Of producing Biooil From Palm Oil Wastes (Bunches, Shells, And Fibers) For Alternative Fuel With Fast Pyrolysis Method). Master Thesis. Universitas Indonesia, Jakarta. Indonesia.

Ram, V. R., Ram, P. N., Khatri, T. T., Vyas, S. J., Dave, P. N. 2014. Thermal analytical characteristics by TGA-DTA-DSC analysis of Carica papaya leaves from Kachchh. International Letters of Natural Sciences. 21: 12-20

Serapiglia, M. J., Mullen, C. A., Boateng, A. A., Dien, B. S., Casler, M.D. 2017. Impact of Harvest Time and Cultivar on Conversion of Switchgrass to Bio-Oils Via Fast Pyrolysis. Bio Energy Research. 10 (2): 388-399.

Sukiran, M. A., Chin, C. M., Abu Bakar, N. K. 2009. Bio-oils from Pyrolysis of Oil Palm Empty Fruit Bunches. American Journal of Applied Sciences. 6 (5): 869-875.

Wattana, W., Kittayaruksakul, R. 2016. Thermal and Physical Characteristics of Fuel Pellets from Para-Rubber Leaf Litter , In: Proceedings of $6^{\text {th }}$ International Conference on Biological, Chemical \& Environmental Sciences (BCES-2016) August 8-9, 2016 Pattaya Thailand). 33-36. 